\title{
Influence of different types of trams on human perception of vibrations in buildings
}

\author{
Alicja Kowalska-Koczwara ${ }^{1, *}$ and Krzysztof Stypuła ${ }^{1}$ \\ ${ }^{1}$ Cracow University of Technology, Institute of Structural Mechanics, 31-155 Kraków, Warszawska \\ 24 St., Poland
}

\begin{abstract}
In an increasingly urbanized areas transport vibration source are closer and closer to the receiver which is a building. At the same time residents requirements for comfort in rooms are higher. In this paper influence of transport vibrations from various types of trams on human perception was tested and analysed. Measurements were made in Cracow on 11 buildings located near tramway. Human perception were investigated according to ISO and Polish standard. Basic RMS method and additional VDV method were applied because of high crest factor of recorded signal. Results of both methods were compared.
\end{abstract}

\section{Introduction}

Buildings, especially in city centers, are subjected to dynamic influences from many dynamic sources: transport, mining activity [1] or seismic [2]. Human perception of vibrations is defined as the effect of mechanical vibration on human body. During normal daily live human body is exposed to different types of vibrations: hand-arm vibrations, whole body vibrations and vibrations transmitted through the soil to the building structure. The first two types of vibration are mainly connected with working area for example with such occupations as bus drivers - effect of whole body vibration $[3,4]$ or builders, carpenters, joiners - effect of handarm vibration [5]. The third one is connected with transport vibrations especially in the city centers $[6,7]$. In this article tramway vibration transmitted through the soil will be considered and influence of different type of trams on human perception of vibration will be investigated. There are two evaluation methods mainly used in the subject of human exposure to vibrations in buildings: root mean square method (RMS) and vibration dose value method (VDV). ISO standard [8] defines RMS method as a basic method of assessment but notes that sometimes additional methods are required. One of additional method which could be considered according ISO standard [8] is VDV method. VDV method is recommended in situations were high value of crest factor exist. Crest factor is defined as follows:

$$
C F=\frac{\left|a_{w}\right|_{P E A K}}{a_{w R M S}}
$$

\footnotetext{
*Corresponding author: akowalska@pk.edu.pl
} 
where: $a_{w P E A K}-$ peak value of weighted acceleration function,

$a_{w R M S}-$ RMS value of weighted acceleration function.

According to ISO standard [8] when CF is equal 9 or higher VDV and RMS method should be both considered, because VDV method is more sensitive to peaks in recorded signal. Below this CF value RMS method is good enough. In Australian standard [9] regulations to the crest factor are more stricter. If $\mathrm{CF}$ is below 6 RMS method should be considered, if CF is in the interval of 6 and 9 both VDV and RMS method should be applied and when CF value is higher than 9 only VDV value should be calculated. British guidelines abandoned using RMS method at all and in Great Britain only VDV method is considered regardless to $\mathrm{CF}$ value [10].

VDV sensitivity for peaks in recorded signal comes from differences in both formulas for RMS and for VDV method. RMS method averages acceleration values in duration time and is defined as:

$$
a_{w}=\left[\frac{1}{T} \int_{0}^{T} a_{w}^{2}(t) d t\right]^{\frac{1}{2}}
$$

where: $a_{w}(t)$ - is weighted acceleration as a function of time $\left[\mathrm{m} / \mathrm{s}^{2}\right]$;

$T-$ is the duration time of measurement [s].

VDV method uses fourth power instead of the second power as is used in RMS and it is defined as follows:

$$
V D V=\left[\int_{0}^{T} a_{w}^{4}(t) d t\right]^{\frac{1}{4}}
$$

In this paper both methods are used for evaluation of human perception to vibrations and results of these methods are compared.

\section{Measurement methodology}

Vibration measurements were carried out before the modernization of the tramway in Krakow city centre. For measurements 11 representative buildings were selected in the so called zone of vibration influences. Ranges of zones of vibration influences are summarized in Table 1.

Table 1. Range of zones of dynamic influences.

\begin{tabular}{|c|c|}
\hline Source of vibration & $\begin{array}{c}\text { Range of zone } \\
{[\mathbf{m}]}\end{array}$ \\
\hline Railway & $25-50$ \\
\hline Tramway, Road & $15-25$ \\
\hline $\begin{array}{c}\text { Line of a shallow } \\
\text { underground }\end{array}$ & 40 \\
\hline
\end{tabular}

Buildings were chosen according to following criteria: building structure, rooms destination, the distance of the building from the track and the nearest road, possibility of access to the 
building and to the rooms localized as close as possible to the source of vibration. Measurement and analysis of the results was carried out using specialized sets of measurement equipment adapted to the measurement and analysis of low frequency vibrations. During measurements vibration acceleration was recorded in the range of $0.15 \mathrm{~Hz}$ to $100 \mathrm{~Hz}$ (range of vibrations influence on people in buildings).

Vibration measurement took place simultaneously at all measurement points located in a single building. Acceleration was recorded in three directions: two horizontal (x, y) and one vertical (z). Measurement points were located according to Polish standards $[11,12]$ as follows:

- $\quad$ one measurement point located on the foundation wall at the ground level,

- at least one measuring point located in the middle of the floor of room intended for human residence (office or residential)

Example of location of measurement point for evaluating the influence of vibration on humans (located in the middle of the floor) is shown in Fig. 1.

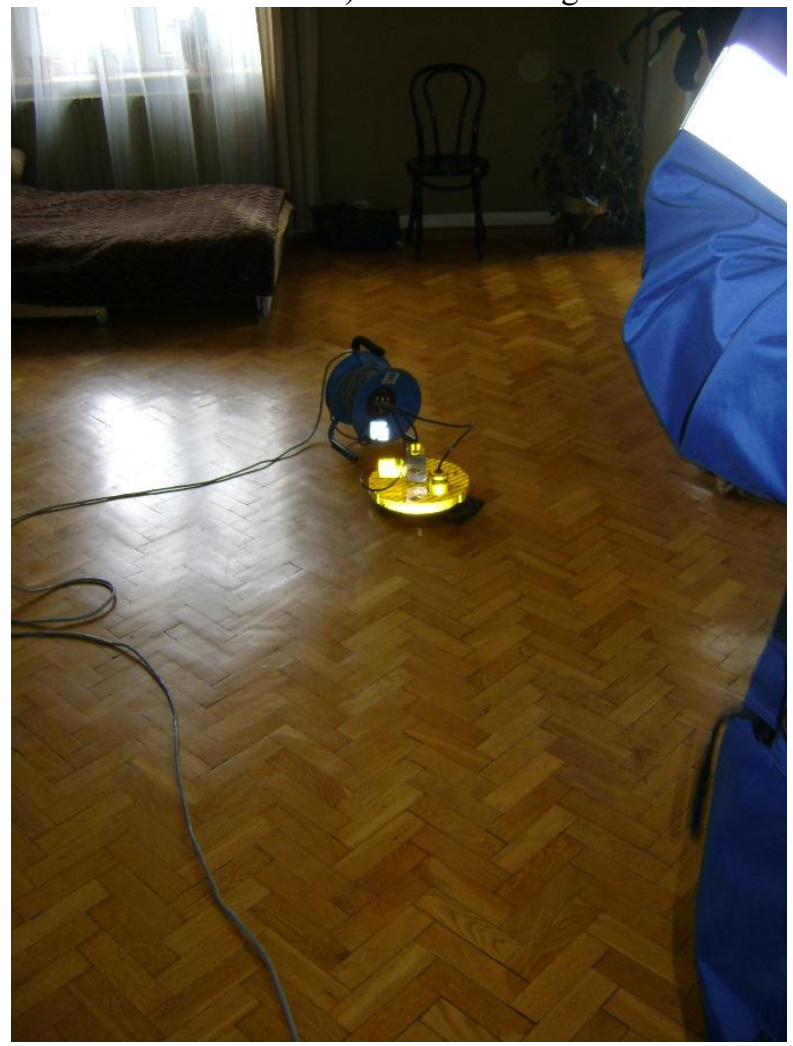

Fig. 1. Location of measurement point for evaluating the influence of vibration on humans.

\section{Analysis of recorded signal}

Analysis of influence of vibration on humans in buildings were made using two evaluation methods: RMS and VDV according to formulas (2) and (3). RMS analysis was made in one third octave bands and is mainly presented as bar graph as on example shown in Fig. 2. 


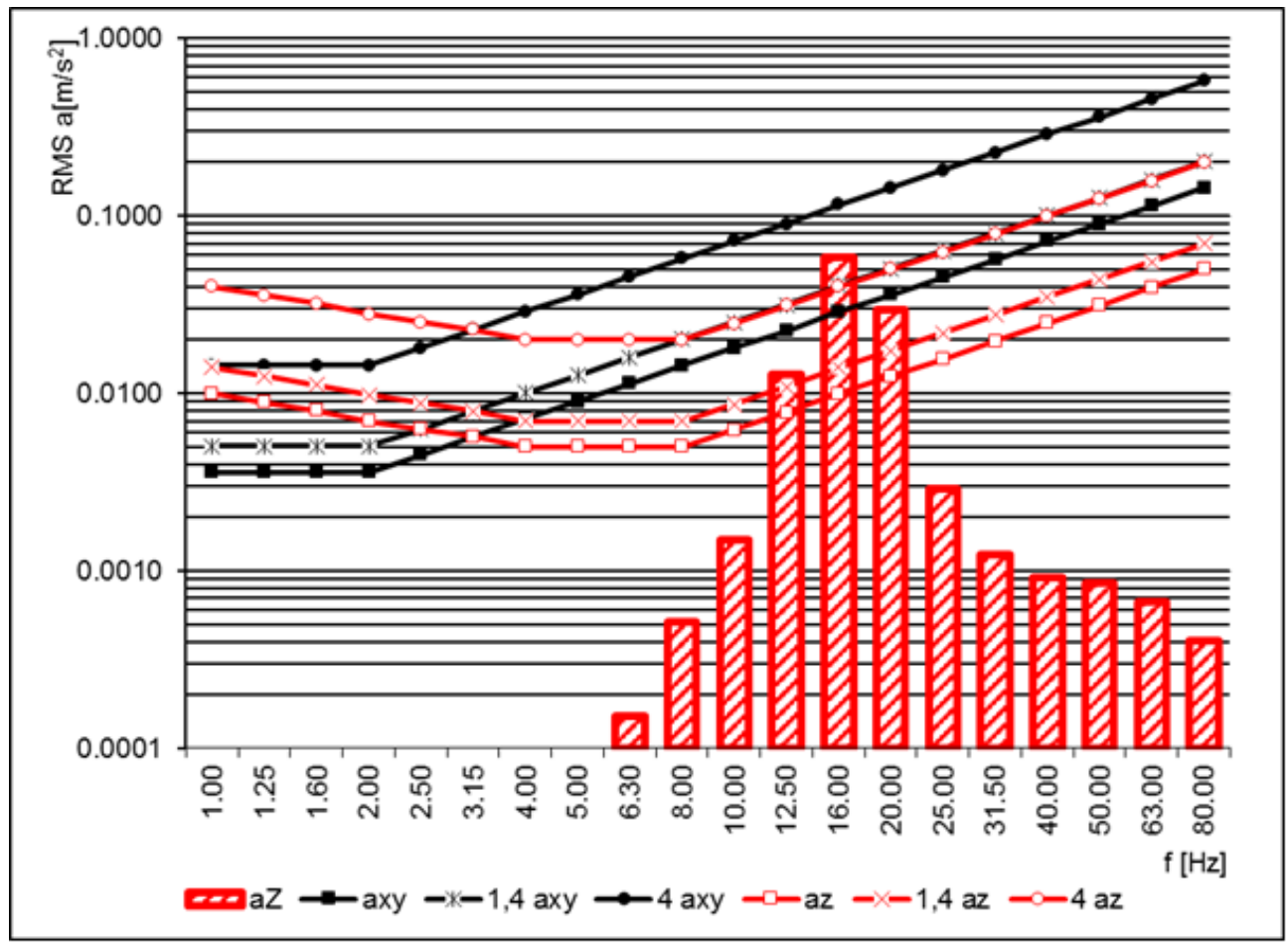

Fig. 2. The most unfavourable results of analyses of the influence of vibration on humans.

On the above figure there are some reference lines which according to ISO standard [8] and Polish standard [12] are interpreted as follows:

- $\quad$ axy - human perception threshold of vibration in $\mathrm{x}$ and $\mathrm{y}$ directions,

- $\quad 1.4$ axy - comfort level during a night in residential buildings in $\mathrm{x}$ and $\mathrm{y}$ directions,

- $\quad 4$ axy - comfort level during a day in residential and office buildings in $\mathrm{x}$ and $\mathrm{y}$ directions,

- $\quad \mathrm{az}$ - human perception threshold of vibration in $\mathrm{z}$ direction,

- $\quad 1.4 \mathrm{az}$ - comfort level during a night in residential buildings in $\mathrm{z}$ direction,

- $\quad 4$ axy - comfort level during a day in residential and office buildings in $\mathrm{z}$ direction.

As a result of VDV procedure one value is obtained. This value should be than compare with table of thresholds (Fig. 3 acc. [10]).

Table 2. Ranges of VDV values.

\begin{tabular}{|c|c|c|c|}
\hline Room destination & $\begin{array}{c}\text { Low probability } \\
\text { of adverse } \\
\text { comments }\end{array}$ & $\begin{array}{c}\text { Adverse } \\
\text { comments } \\
\text { possible }\end{array}$ & $\begin{array}{c}\text { Adverse } \\
\text { comments } \\
\text { probable }\end{array}$ \\
\hline $\begin{array}{c}\text { Residential buildings - } \\
\text { 16h day }\end{array}$ & $0.2-0.4$ & $0.4-0.8$ & $0.8-1.6$ \\
\hline $\begin{array}{c}\text { Residential buildings - } \\
\text { 8h night }\end{array}$ & $0.1-0.2$ & $0.2-0.4$ & $0.4-0.8$ \\
\hline $\begin{array}{c}\text { Office buildings - } \\
\text { 16h day }\end{array}$ & $0.4-0.8$ & $0.8-1.6$ & $1.6-3.2$ \\
\hline Workshops - 16h day & $0.8-1.6$ & $1.6-3.2$ & $3.2-6.4$ \\
\hline
\end{tabular}


Listed in Table $2 V D V$ values refer to whole day or whole night human exposure to vibrations, not to one dynamical episode. That is why having $V D V_{i}$ values for one episode, whole day or night exposure for $\mathrm{N}$ episodes should be calculated according to formula (4):

$$
V D V_{\text {total }}=\left(\sum_{i}^{N} V D V_{i}^{4}\right)^{\frac{1}{4}}
$$

To compare RMS and VDV analysis results, to RMS analysis so called WODL coefficient (in English, the human vibration perceptivity ratio - HVPR), proposed in [13] should be applied:

$$
W O D L=\max \left(\frac{a R M S}{a z}\right)
$$

where:

aRMS - acceleration RMS value obtained from analysis;

$a z$ - acceleration RMS value equivalent to the threshold for the perception of vibration in a $\mathrm{z}$-direction in the same $1 / 3$ octave band in which aRMS was obtained.

This coefficient is very useful because it describes if and how much human perception threshold is exceeded.

\section{Results of analysis}

Analysis was made using RMS and VDV method, for comparison $V D V_{\text {total }}$ and $W O D L$ values were calculated. To show differences between different types of trams the results of analysis are divided not only to methods of evaluation but also to various trams. Episodes of maximum values were chosen for comparison. Because measurements were made in daytime only daily exposure to vibration was compared. In VDV analysis according to timetable of trams some assumption was made during daytime tram passes for every 5 minutes, which gives 192 tram passages. Summary of results of VDV analysis is listed in Table 3.

\begin{tabular}{|c|c|c|c|c|c|c|c|}
\hline \multirow{2}{*}{ No. } & \multirow{2}{*}{\multicolumn{2}{|c|}{ Building type }} & \multicolumn{5}{|c|}{ Tram type } \\
\hline & & & $105 \mathrm{~N}$ & EU8N & GT8S & E1-C3 & GT6 \\
\hline \multirow{2}{*}{1} & \multirow{2}{*}{$\begin{array}{l}\text { masonry four } \\
\text { storey residential } \\
\text { building }\end{array}$} & $\begin{array}{c}W O D L \\
\max \end{array}$ & & $\begin{array}{c}5.87 \\
(f=16 \mathrm{~Hz}) \\
\end{array}$ & & & \\
\hline & & $V D V$ & 0.343 & 0.793 & 0.268 & 0.127 & - \\
\hline \multirow{2}{*}{2} & \multirow{2}{*}{$\begin{array}{l}\text { masonry two storey } \\
\text { residential building }\end{array}$} & $\begin{array}{l}W O D L \\
\max \end{array}$ & & $\begin{array}{c}10.97 \\
(f=8 \mathrm{~Hz}) \\
\end{array}$ & & & \\
\hline & & $V D V$ & 0.457 & 0.167 & 0.340 & 0.216 & 0.219 \\
\hline \multirow{2}{*}{3} & \multirow{2}{*}{$\begin{array}{c}\text { Reinforced } \\
\text { concrete } 10 \text {-storey } \\
\text { office building }\end{array}$} & $\begin{array}{l}W O D L \\
\max \end{array}$ & $\begin{array}{c}1.95 \\
(f=10 \mathrm{~Hz})\end{array}$ & & & & \\
\hline & & $V D V$ & 0.228 & 0.070 & 0.072 & 0.211 & 0.058 \\
\hline \multirow{2}{*}{4} & \multirow{2}{*}{$\begin{array}{l}\text { masonry five storey } \\
\text { residential building }\end{array}$} & $\begin{array}{l}\text { WODL } \\
\max \end{array}$ & & & & & $\begin{array}{c}1.34 \\
(f=50 \mathrm{~Hz})\end{array}$ \\
\hline & & $V D V$ & 0.442 & 0.875 & - & 0.762 & 1.159 \\
\hline
\end{tabular}

Table 3. Results of VDV analysis. 


\begin{tabular}{|c|c|c|c|c|c|c|c|}
\hline \multirow{2}{*}{5} & \multirow{2}{*}{$\begin{array}{l}\text { masonry two storey } \\
\text { residential building }\end{array}$} & $\begin{array}{c}W O D L \\
\max \end{array}$ & $\begin{array}{c}3.22 \\
(f=20 \mathrm{~Hz})\end{array}$ & & & & \\
\hline & & $V D V$ & 0.750 & 0.455 & - & 0.452 & 0.339 \\
\hline \multirow{2}{*}{6} & \multirow{2}{*}{$\begin{array}{l}\text { masonry three } \\
\text { storey residential } \\
\text { building }\end{array}$} & $\begin{array}{c}W O D L \\
\max \end{array}$ & $\begin{array}{c}7.61 \\
(f=10 \mathrm{~Hz})\end{array}$ & & & & \\
\hline & & $V D V$ & 0.776 & 0.363 & 0.293 & 0.463 & 0.425 \\
\hline \multirow{2}{*}{7} & \multirow{2}{*}{$\begin{array}{l}\text { Reinforced } \\
\text { concrete three } \\
\text { storey office } \\
\text { building }\end{array}$} & $\begin{array}{l}W O D L \\
\max \end{array}$ & $\begin{array}{c}1.40 \\
(f=20 \mathrm{~Hz})\end{array}$ & & & & \\
\hline & & $V D V$ & 1.098 & 0.452 & 0.317 & 0.475 & 0.355 \\
\hline \multirow{2}{*}{8} & \multirow{2}{*}{$\begin{array}{l}\text { Reinforced } \\
\text { concrete } 8 \text {-storey } \\
\text { residential building }\end{array}$} & $\begin{array}{l}\text { WODL } \\
\max \end{array}$ & $\begin{array}{c}1.92 \\
(f=12.5 \mathrm{~Hz})\end{array}$ & & & & \\
\hline & & $V D V$ & 0.199 & 0.264 & - & 0.117 & 0.068 \\
\hline \multirow{2}{*}{9} & \multirow{2}{*}{$\begin{array}{l}\text { masonry two storey } \\
\text { residential building }\end{array}$} & $\begin{array}{l}\text { WODL } \\
\max \end{array}$ & $\begin{array}{c}2.51 \\
(f=8 \mathrm{~Hz})\end{array}$ & & & & \\
\hline & & $V D V$ & 0.685 & 0.102 & 0.223 & 0.366 & - \\
\hline \multirow{2}{*}{10} & \multirow{2}{*}{$\begin{array}{l}\text { masonry two storey } \\
\text { residential building }\end{array}$} & $\begin{array}{c}W O D L \\
\max \end{array}$ & & & & $\begin{array}{c}14.36 \\
(f=10 \mathrm{~Hz})\end{array}$ & \\
\hline & & $V D V$ & 0.907 & 1.188 & 0.287 & 1.952 & 0.359 \\
\hline \multirow{2}{*}{11} & \multirow{2}{*}{$\begin{array}{l}\text { masonry 6-storey } \\
\text { residential building }\end{array}$} & $\begin{array}{l}\text { WODL } \\
\max \end{array}$ & $\begin{array}{c}0.81 \\
(f=20 \mathrm{~Hz})\end{array}$ & & & & \\
\hline & & $V D V$ & 0.291 & - & - & 0.209 & 0.134 \\
\hline
\end{tabular}

As could be seen from above Table 3 the highest values of $V D V_{\text {total }}$ are obtained for almost the same type of tram for each building excluding 8 storey reinforced concrete residential building (No. 8) in which differences in highest values of $V D V$ are close to each other and excluding 2 storey masonry residential building (No. 2).

RMS analysis suggests that for almost every building (excluding the last one, No. 11) there is although one episode for which human perception threshold is exceeded. Meanwhile in VDV analysis similarly as in RMS analysis for only one building threshold is not exceeded, but this time it is building No. 3. There is simple explanation of this situation. In RMS analysis threshold is not connected with destination of the room, only comfort level is. In VDV analysis all ranges are connected to the destination of the room.

Analysing comfort level for both analysis there could be seen some similarities and differences. For building No. 1 and 10 results of both analysis are the same - comfort level is exceeded or is on the edge. But there are differences for buildings No. 2, 4 and 6. The highest difference is for 2 storey masonry building No. 2. $V D V$ vale is in the middle range while $W O D L$ value is equal 10.97 which means that comfort level highly exceeded. The reverse situation occurred for building No. 4 in which $V D V$ suggests that comfort is exceeded while $W O D L$ value is equal 1.34. For building No. $6 \mathrm{VDV}$ is close to comfort level so both analysis can be interpreted as close to each other.

\section{Conclusion}

The article presents two methods of assessment and their application in analysis of influence of vibration on humans. It describes the procedures which should be used in such evaluations. 
Differences and similarities between both methods of assessment are described and are shown on an exemplary analysis.

Analysis presented in this paper is based on measurements results that were carried out in 2013 in Krakow. Mostly measurements of human exposure to transport vibration concern on passanger or drivers comfort not on vibrational comfort for ground born vibration transmitted to buildings that can influence on humans in buildings. An interesting conclusion can be found in [14] in which RMS analysis and $\mathrm{KB}_{\mathrm{F}}$ analysis (from German standard [15]) are compared, unfortunately conclusions are made based on numerical results.

Regarding results from analysis of influence of different types of trams which is based on measurements in this article some conclusion can be drawn:

- results from evaluation of human perception to vibration made using RMS and VDV analysis are mostly close to each other, but there are some vibrational episodes in which differences are significant,

- there are some situation especially of high value of crest factor in which is good to made evaluation of human exposure to vibration using basic RMS method and one of additional methods (for example VDV) given in ISO standard [8],

- $\quad$ in most analyzed dynamical episodes the highest RMS and WODL values occurred for tram type $105 \mathrm{~N}$, which should be expected because this is an old type of tram and very used,

- $\quad$ the highest value both RMS and WODL of all measured episodes occurred for tram type E1-C3 which is also an old tram called « nuremberg » but nowadays this type of tram is phased out from Krakow tram network,

- exceeding occurred also for tram type EU8N - there are upgraded wagons withdrawn from use on the light metro line U6 in Vienna.

\section{References}

1. T. Tatara, F. Pachla, P. Kuboń. Bull Earthquake Eng (2016)

2. L.A. Padrón, J.J. Aznárez, O. Maeso, Soil Dyn and Earthquake Eng, 29, (2009)

3. R.P. Blood, J.D. Ploger, M.G. Yost, R.P. Ching, P.W. Johnson, J. Sound Vib. 329 (2010)

4. O. Thamsuwan, R. P. Blood, R. P. Ching, L. Boyle, P. W. Johnson, Int J Ind Ergonom 43 (2013)

5. K. T. Palmer, M. J. Grifin, H. Syddall, B. Pannett, C. Cooper, D. Coggon. Am J Ind Med 39 (2001)

6. D. C. Waddington, J. Woodcock, E. Peris, J. Condie, G. Sica, A. T. Moorhouse, A. Steele, The J. of the Acous. Soc. of Am. 135 (2014)

7. H. Hao, T.C. Anga, J. Shen. Build Environ 36 (2001)

8. ISO 2631-1, Guide to the evaluation of human exposure to whole body vibration. Part 1 - General requirements, (2003)

9. AS 2670.2: Evaluation of human exposure to whole-body vibration - Continuous and shock-induced vibration in buildings ( $1 \mathrm{~Hz}$ to $80 \mathrm{~Hz}$ ), (1990)

10. BS 6472-1, Guide to evaluation of human exposure to vibration in buildings, Part 1: Vibration sources other than blasting, (2008)

11. PN-85/B-02170: Ocena szkodliwości drgań przekazywanych przez podłoże na budynki / Evaluation of the harmfulness of building vibrations due to ground motion, (1985)

12. PN-88/B-02171: Ocena wpływu drgań na ludzi w budynkach / Evaluation of vibrations influence on people in buildings, (1988) 
13. J. Kawecki, K. Stypuła Ensuring vibrational comfort for people in buildings exposed for transport impact (in Polish). (Publishing House of Cracow University of Technology, Cracow 2013)

14. G. Kouroussis, N. Pauwels, P. Brux, C. Conti, O. Verlinden, Sci Total Environ 482-483 (2014)

15. DIN 4150-2, Structural vibration, Part 2: Human exposure to vibration in buildings, (1999) 